\title{
Barbara Krawcowicz
}

Norwegian University of Science and Technology

barbara.krawcowicz@ntnu.no

\section{Teodycea w czasie Zagłady. Wojenne kazania rabina Szlomy Zalmana Unsdorfera}

\begin{abstract}
Streszczenie
Wiele analiz wpływu, jaki Zagłada wywarła na żydowską teologię, podkreśla wymiar braku kontynuacji - w tym ujęciu Zagłada jako wydarzenie bez precedensu postawiła przed żydowską teologią nowe pytania i równocześnie radykalnie zakwestionowała tradycyjne odpowiedzi. Powstałe w czasie wojny pisma ortodoksyjnych rabinów, którzy byli świadkami oraz ofiarami narastających represji, stanowią fascynujący materiał źródłowy, a jego analiza pozwala nakreślić obraz przeobrażeń żydowskiej teologii w odpowiedzi na Holokaust. Autorka przedstawia w artykule interpretację wojennych kazań rabina Szlomy Zalmana Unsdorfera, kładąc nacisk na to, w jak wielu wymiarach myśl Unsdorfera stanowi kontynuację wybranych wątków tradycji rabinicznej i w jaki sposób wpisuje się ona raczej w ramy tradycyjnych żydowskich odpowiedzi teologicznych na historyczne katastrofy, niż poza nie wykracza.
\end{abstract}

\section{Słowa kluczowe}

teologia, ortodoksyjny judaizm, teodycea, historia, Szlomo Zalman Unsdorfer

\begin{abstract}
Many analyses of the Holocaust's influence on Jewish theology emphasize the dimension of the lack of continuation. From this perspective the Holocaust, as an unprecedented event, made the Jewish theology face new inquiries, at the same time radically questioning the traditional answers. The wartime letters written by Orthodox rabbis who were witnesses to and victims of the intensifying repressions constitute a fascinating primary source, the analysis of which makes it possible to paint a picture of the transformation of Jewish theology in reaction to the Holocaust. Krawcowicz presents an interpretation of rabbi Szlomo Zalman Unsdorfer's wartime sermons, laying stress on the many dimensions in which Unsdorfer's thought is a continuation of selected threads of rabbinical tradition and the way in which it fits into the framework of the traditional Jewish theological responses to historical catastrophes rather than reach beyond them.
\end{abstract}

\section{Key words}

theology, Orthodox Judaism, theodicy, history, Szlomo Zalman Unsdorfer 
W 1970 r. Emil Fackenheim, jeden z najwybitniejszych żydowskich teologów XX w., napisał, iż waga pytań postawionych przez rzeczywistość Zagłady była tak wielka, że „do niedawna żydowska myśl teologiczna milczała na temat Holokaustu. Dobrze uzasadnione bojaźń i drżenie [...] trzymały żydowską refleksję teologiczną w milczeniu na podobieństwo milczenia Hioba"1. Dziś wiemy, że słowa Fackenheima nie odpowiadały w pełni rzeczywistości. Żydowska teologia podjęła pytania stawiane przez Zagładę znacznie wcześniej, niż sądził. Co więcej, same lata Zagłady również nie były okresem milczenia. W czasie, kiedy dokonywało się zniszczenie żydowskiego życia, żydowska myśl religijna trwała, znajdując wyraz w kazaniach, traktatach teologicznych, okazjonalnych przemówieniach i listach.

Charakter żydowskich reakcji na Zagładę zarówno podczas wojny, jak i po niej w znacznej mierze określał istniejący repertuar światopoglądów religijnych i świeckich. Dla znacznej części żydowskiej społeczności, szczególnie w Europie Wschodniej, ścieżka wiary i praktyki religijnej była najbardziej naturalna nawet - a może przede wszystkim - w sytuacji kryzysu i konfrontacji z przemocą. Jest oczywiste, że rozmaite aspekty złożonego procesu modernizacji spowodowały głębokie przeobrażenia żydowskiego życia. Niemniej wielu Żydom ukształtowanym przez tradycyjną edukację to tradycja właśnie zapewniała podstawowy system odniesienia, język, zasób pojęć i zachowań, które wyznaczały ścieżkę myśli i działania w czasie prześladowań. Uwidacznia się to bardzo wyraźnie w zachowanych pismach ortodoksyjnych rabinów z okresu Zagłady. Dla nich Tora - złożona z Biblii Hebrajskiej oraz bogatej tradycji rabinicznej - stanowiła podstawowy pryzmat, przez który patrzyli na otaczającą ich rzeczywistość. Stojąc wobec tragedii prześladowań i zniszczenia, to w Torze właśnie poszukiwali wskazówek, w jaki sposób zrozumieć katastrofę, której byli świadkami.

W poniższych rozważaniach proponuję odczytanie wojennych kazań rabina Szlomy Zalmana Unsdorfera w kontekście teodycei rozumianej, za Peterem Bergerem, jako próba zapewnienia religijnej legitymizacji zjawiskom anomicznym, czyli niosącym ze sobą niebezpieczeństwo destabilizacji istniejącego ładu². Obrana przeze mnie ścieżka interpretacyjna uwypukla element kontynuacji w żydowskiej myśli religijnej. Problem teodycei, pytanie o źródła i naturę cierpienia może być postrzegany jako jedna z zasadniczych trudności, z jakimi musi się uporać monoteistyczna teologia, która z jednej strony zakłada istnienie dobrego i troszczącego się o stworzenie Bytu Najwyższego, a z drugiej nie chce zanegować realności zła. W żydowskiej tradycji teologicznej problem teodycei, pytanie o źródła cierpienia w ich zbiorowym wymiarze jest ściśle powiązane z ideą przymierza, szczególnej relacji istniejącej pomiędzy Bogiem a Izraelem. Jednym z najważniejszych aspektów idei przymierza, jak przedstawia je literatura biblij-

\footnotetext{
${ }^{1}$ Emil L. Fackenheim, God's Presence in History, New York: Harper and Row, 1970, s. 70-71.

${ }^{2}$ Zob. Peter Berger, The Sacred Canopy: Elements of a Sociological Theory of Religion, New York: Anchor Books, 1969, s. 55.
} 
na i rabiniczna, jest to, że nadaje ono sens historii. Postrzegane z perspektywy przymierza dzieje przestają być jedynie sekwencją wydarzeń, których znaczenie nie wykracza poza czasowo ograniczony horyzont ludzkiej percepcji. Idea przymierza przeobraża historię z opowieści o ludzkich wzlotach i upadkach w teofanię, w scenę, na której rozwija się relacja między Izraelem i Bogiem. W swoich kazaniach Szlomo Zalman Unsdorfer przedstawiał prześladowania, których był świadkiem i ostatecznie ofiarą, z tej właśnie perspektywy, a jego rozważania podążają ścieżkami, którymi wieki przed nim podążali autorzy tekstów biblijnych i rabinicznych.

Szlomo Zalman Unsdorfer urodził się w Bratysławie w 1888 r. i w tym mieście spędził większość życia jako aktywny członek ortodoksyjnej społeczności żydowskiej. W młodości studiował w słynnej bratysławskiej jesziwie założonej przez Chatam Sofera - Mojżesza Schreibera, jednego z liderów ortodoksyjnych Żydów w pierwszej połowie XIX w. Z pomocą prawnuka Chatam Sofera, który kierował wówczas jesziwą, Unsdorfer założył w 1915 r. Bractwo Poszukiwaczy Drogi (Chewra Mewakszej Derech), które z czasem liczyło ponad czterystu członków. W sobotnie wieczory Unsdorfer wygłaszał dla nich specjalne wykłady w Wielkiej Synagodze. Od połowy lat dwudziestych służył także jako rabin jednej z bratysławskich synagog.

Od marca 1939 r. Bratysława była stolicą nominalnie niepodległej Republiki Słowackiej. Antyżydowska przemoc zdarzała się w mieście wcześniej, ale sytuacja żydowskich mieszkańców Bratysławy pogorszyła się znacznie od dnia, kiedy władzę na Słowacji oficjalnie objęła pronazistowska Słowacka Partia Ludowa. Do jesieni $1941 \mathrm{r}$. Żydzi Bratysławy zostali praktycznie odizolowani od reszty społeczeństwa. Rozwiązano żydowskie organizacje, zlikwidowano żydowskie gazety. Naznaczeni żółtymi gwiazdami Dawida, Żydzi byli zmuszani do ciężkich robót i spotykali się z przemocą na ulicach. We wrześniu 1941 r. z miasta wysiedlono 10 tys. spośród pozostających jeszcze w Bratysławie 15 tys. Żydów ${ }^{3}$. Kazano im porzucić domy i iść w nieznane, jak Unsdorfer zapisał na marginesie kazania. W październiku tego samego roku, zastanawiając się nad biblijną sceną, w której Bóg nakazuje Abrahamowi, by opuścił ziemię swoich ojców, Unsdorfer odniósł ten fragment bezpośrednio do sytuacji bratysławskich Żydów - los Abrahama stał się ich losem. W biblijnej przeszłości Bóg poddał wiarę Abrahama próbie, nakazując mu, by opuścił rodzinne strony. Teraz, zauważył Unsdorfer, przed taką samą próbą stali jego potomkowie. Czy rzeczywiście przed taką

${ }^{3}$ Więcej informacji na temat losów słowackich Żydów w czasie Zagłady można znaleźć w: Gila Fatran, Haim maawak al hisardut: hanhagat Jehudej Slowakia ba-Szoa 1938-1944, Tel Awiw: Moreszet i Institute of Contemporary Jewry, 1992; The Tragedy of the Jews of Slovakia: 1938-1945. Slovakia and the "Final Solution of the Jewish Question", red. Wacław Długoborski, Jarosław Mensfelt, Oświęcim: Auschwitz-Birkenau State Museum, Banska Bystica: Museum of the Slovak National Uprising, 2002; Livia Rothkirchen, The Destruction of Slovak Jewry (1942-1944): A Documentary History, Jerusalem: Yad Vashem, 1961. 
samą? Czyż okoliczności nie były kompletnie odmienne? Z jednej strony oczywiście były odmienne. $Z$ drugiej strony jednak za kluczowe Unsdorfer uznał podobieństwo, a nie różnicę. W Biblii do Abrahama zwrócił się z nakazem Bóg. W Bratysławie rozkaz o przesiedleniu wydały słowackie władze. Unsdorfer nie miał jednak wątpliwości: nakaz przesiedlenia nie miał źródła wyłącznie w ludzkich umysłach. Jego ostatecznym źródłem była wola Boga.

We wrześniu 1944 r. Unsdorfer opuścił Bratysławę. Z fałszywym amerykańskim paszportem znalazł się w obozie przejściowym w Marienthal z nadzieją na ocalenie w ramach wymiany jeńców. Plany spaliły jednak na panewce, gdy odkryto jego prawdziwą tożsamość. W październiku 1944 r. Unsdorfer został deportowany i zamordowany w Auschwitz-Birkenau. Jego syn Simcha Bunem przeżył Auschwitz i po wyzwoleniu obozu wrócił do Bratysławy, gdzie w ruinach rodzinnego domu odnalazł zapiski ojca. Zostały one przetłumaczone z jidysz na hebrajski i opublikowane pod tytułem Siftej Szlomo (Usta Szlomy) ${ }^{4}$. Niestety, nigdy nie udało się odnaleźć oryginalnego tekstu. Wedle wspomnień syna, Unsdorfer przygotowywał swoje kazania dzień przed ich wygłoszeniem, a czasem dodawał na marginesach notatki dotyczące aktualnych wydarzeń ${ }^{5}$. $\mathrm{Z}$ tych zapisków dowiadujemy się na przykład, że 6 listopada $1938 \mathrm{r}$. lokalne bandy włamały się do bratysławskich synagog, latem $1939 \mathrm{r}$. w podobnej napaści zniszczono zwoje Tory Wielkiej Synagogi, rok później, latem 1940 r., wiele żydowskich rodzin zostało wyeksmitowanych i zmuszonych przeprowadzić się do znacznie mniejszych pomieszczeń, a 30 listopada tego samego roku na społeczność żydowską nałożono nowy, bardzo wysoki podatek ${ }^{6}$.

Zapisane przez Unsdorfera kazania, okolicznościowe przemówienia, komentarze do Pirkej Awot stanowią fascynujący przykład konfrontacji tradycyjnych kategorii żydowskiej myśli religijnej z rzeczywistością, która zdawała się podważać same ich fundamenty. Narastające prześladowania zmuszały Unsdorfera do podjęcia próby sformułowania odpowiedzi na pytanie, dlaczego cierpienie dotykało słowackich Żydów. Odpowiedzi na nie poszukiwał w pojęciowym świecie określonym przez Torę Ustną i Pisaną.

\footnotetext{
${ }^{4}$ Szlomo Zalman Unsdorfer, Siftej Szlomo, Brooklyn, NY: Balszon Printing, 1972.

${ }^{5}$ Szmuel Aleksander Unsdorfer, Przedmowa pograżonego w żałobie syna Autora [w:] ibidem, s. 8-20. W złożonym w Yad Vashem świadectwie David Steiner z Bratysławy wspomina, że kazania Unsdorfera zawsze odnosiły się do aktualnych wydarzeń (Archiwum Yad Vashem, 0.3/10349). Zob. Gershon Greenberg, The Suffering of the Righteous According to Shlomo Zalman Unsdorfer of Bratislava, 1939-1944 [w:] Remembering for the Future: The Holocaust in an Age of Genocide, red. John Roth, New York: Palgrave, 2001, s. 422-438; idem, Shlomo Zalman Unsdorfer: With God Through the Holocaust, „Yad Vashem Studies” 2003, t. 31, s. 61-94.

${ }^{6}$ Siftej Szlomo..., s. 159-160, 303-307, 141-144, 32-33, 170-172, 50-52.
} 


\section{Mipnej chatenu}

Dominująca, aczkolwiek nie jedyna w żydowskiej tradycji, odpowiedź na pytanie o źródła nieszczęść i katastrof dotykających naród żydowski tłumaczy je w kategoriach kary za grzech:

I stanie się, jeżeli zawsze będziecie zważać na moje przykazania, które ja wam nakazuję dzisiaj, że będziecie kochać Pana, waszego Boga, i będziecie mu służyli całym swoim sercem i całą swoją duszą, wówczas ześlę wcześniejszy i późniejszy deszcz na waszą ziemię we właściwym czasie i będziecie zbierać wasze zboże, wino i oliwę. Dam trawę na twoim polu dla twojego bydła i będziesz jadł i nasycisz się. Strzeżcie się i nie dajcie się omamić waszemu sercu, żebyście się nie odwrócili i nie służyli bożkom narodów i nie kłaniali się im. Bo gniew Boga zapłonie przeciwko wam! Powstrzyma niebiosa, tak że deszczu nie będzie, ziemia nie wyda swojego plonu i zostaniecie szybko wytraceni z dobrej ziemi, którą Bóg dał wam. (Pwt 11:13-21) ${ }^{7}$

Przytoczony fragment biblijnej Księgi Powtórzonego Prawa stanowi część jednej z najważniejszych żydowskich modlitw - Szema Israel, która, recytowana, zgodnie z rabinicznymi zaleceniami, dwa razy dziennie, zawiera w skondensowanej formie fundamenty żydowskiej teologii. Ten fragment, wraz z wersetami 4-6 z dziewiątego rozdziału księgi, jest zawarty również w mezuzach i zwojach tefilin i opisuje jeden z podstawowych mechanizmów kształtujących ustanowioną przez przymierze relację pomiędzy Bogiem a Izraelem - związek między niewiernością i odpłatą, grzechem i karą. Przymierze, wedle autorów Księgi Powtórzonego Prawa, postawiło przed Izraelem wybór dobitnie wyrażony w tych oto słowach:

Patrz, kładę przed tobą dzisiaj błogosławieństwo i przekleństwo. Błogosławieństwo, kiedy będziecie słuchać przykazań Pana, waszego Boga, które ja dziś wam nakazuję, a przekleństwo, jeżeli nie będziecie słuchać przykazań Pana, waszego Boga, i zbaczając z drogi, którą ja nakazuję wam dzisiaj, idąc za bożkami narodów [...]. (Pwt 11:26-28)

Księga Powtórzonego Prawa zawiera podstawową formę teodycei przymierza, tj. teodycei, która konceptualizuje cierpienie przez pryzmat relacji między Izraelem i Bogiem. Zakłada ona, że nieszczęścia oraz cierpienia w ich zbiorowym wymiarze stanowią konieczną i zasłużoną odpłatę za niedotrzymanie warunków zawartego paktu. Dodatkową przesłanką deuteronomicznej teodycei przymierza jest boska doskonałość. Jak stwierdza się we fragmencie zwanym Pieśnią Mojżesza: „Potężny, którego dzieła są doskonałe, bo wszystkie jego drogi są prawością. Bóg ufności, bez niesprawiedliwości. Przekupstwo nie jego, to skaza jego synów - pokolenia przewrotnych i wypaczonych" (Pwt 32:4-5). Bóg

${ }^{7}$ Wszystkie fragmenty Pięcioksięgu cytowane w przekładzie Pardes Lauder. Pozostałe fragmenty biblijne w przekładzie własnym. 
opisany przez autorów Księgi Powtórzonego Prawa oraz deuteronomicznej historii ${ }^{8}$ jest nie tylko aktywnym, lecz także doskonałym w swej prawości uczestnikiem dziejów. W ostatecznym rozrachunku losy Izraela są kształtowane przez boską odpowiedź na jego działania:

Wówczas Izraelici czynili to, co złe w oczach Pana i służyli Baalom. Opuścili Boga swoich ojców [...] i poszli za cudzymi bogami, którzy należeli do ludów sąsiednich. [...] Wówczas zapłonął gniew Boga przeciwko Izraelitom, tak że wydał ich w ręce grabieżców, którzy ich złupili, wydał ich na łup nieprzyjaciół, którzy ich otaczali, tak że nie mogli im się oprzeć. Dokądkolwiek się zwracali, ręka Boga była przeciwko nim na ich nieszczęście, jak Bóg im zapowiedział i jak im poprzysiągł. I byli bardzo ciemiężeni. (Sdz 2:11-17)

Opowieść, która następuje po tym podsumowaniu historii Izraelitów w okresie Sędziów, toczy się wedle tego samego wzorca: grzech bałwochwalstwa za każdym razem pociąga za sobą karę w postaci klęski militarnej i opresji. Zgodnie z tą samą regułą Księga Królów tłumaczy upadek Samarii i Judy:

Król asyryjski najechał cały kraj, przyszedł pod Samarię i oblegał ją przez trzy lata. W dziewiątym roku [panowania] Ozeasza król asyryjski zdobył Samarię i zabrał Izraelitów w niewolę do Asyrii [...]. Stało się tak, bo Izraelici zgrzeszyli przeciwko Panu, Bogu swemu, który ich wyprowadził z Egiptu [...]. Czcili bogów obcych i naśladowali obyczaje ludów, które Bóg wypędził przed Izraelitami [...]. Odrzucili przykazania Jego i przymierze, które zawarł z przodkami, oraz rozkazy, które im wydał. (2 Krl 17:5-15)

Autorzy deuteronomicznej historii nie pozostawiają najmniejszych wątpliwości co do tego, że zwycięstwo Asyrii było rezultatem grzechów popełnionych przez mieszkańców Samarii. Ani militarne, ani polityczne aspekty sytuacji nie

\footnotetext{
${ }^{8}$ Hipotezę, wedle której księgi Powtórzonego Prawa, Jozuego, Sędziów oraz Królów stanowiły jedną całość, przedstawił w 1943 r. Martin Noth w pracy Überlieferungsgeschichtliche Studien. Die sammelnden und bearbeitended Geschichtswerke im Alten Testament (wyd. 3, Darmstadt: Wissenschaftliche Buchgesellschaft, 1967; angielskie tłumaczenie pierwszej części: The Deuteronomistic History, Sheffield: Sheffield Academic Press, 1981 [„Journal for the Study of the Old Testament Supplement" 15]). Noth nazwał tę kompozycję historią deuteronomiczną i argumentował, że została ona stworzona przez jednego autora, którego intencją było odpowiedzenie na pytanie o powody upadku Judy i Samarii. Obecnie najczęściej uznaje się historię deuteronomiczną za tekst napisany i redagowany w okresie od VII wieku p.n.e. do czasów po zakończeniu niewoli babilońskiej. Znakomite omówienie stanu badań nad historią deuteronomiczną oraz nowatorską interpretację tekstu zawiera praca Thomasa C. Römera The So-Called Deuteronomistic History: A Sociological, Historical and Literary Introduction (London: T\&T Clark, 2005 i 2007). Jan Assmann trafnie określił historię deuteronomiczną mianem historii winy (idem, Guilt and Remembrance: On the Theologization of History in the Ancient near East, „History and Memory”, jesień 1990, t. 2, nr 1). Niezależnie od szczegółów dotyczących historii kompozycji historii deuteronomicznej może być ona traktowana jako pierwsza w żydowskiej tradycji próba całościowej interpretacji historii Izraelitów z perspektywy przymierza.
} 
mają tutaj znaczenia. Zniszczenie północnego królestwa Izraelitów nie dokonało się dlatego, że słaba Samaria została zmiażdżona przez rosnącą w siłę Asyrię, ale dlatego że „Izraelici zgrzeszyli przeciwko Panu”. Grzech musi zostać ukarany i to ten mechanizm przymierza wyjaśnia zwycięstwo Asyrii, w słowach proroka opisanej jako rózga bożego gniewu (Iz 10:5). Podobny los czekał mieszkańców południowego królestwa, które padło ofiarą Babilonu z powodu grzechów Manassesa, ponieważ czynił on to, „co było złe w oczach Boga” (2 Krl 21:2) ${ }^{9}$. Deuteronomiczna historia przedstawia dzieje Izraela nie tylko jako opowieść o wzlotach jednych i upadkach innych, lecz jako scenę, na której raz po raz dokonuje się boska interwencja. Dzieje Izraela to teofania, której logikę wyznaczają zasady przymierza między Izraelem i Bogiem.

Interpretacja zbiorowego cierpienia, naturalnych bądź politycznych katastrof i nieszczęść w kategoriach sprawiedliwej odpłaty za niedotrzymanie warunków przymierza nie jest w Biblii jedyną formą teodycei. Wypracowana przez autorów Księgi Powtórzonego Prawa oraz deuteronomicznej historii retrybutywna teodycea powstała w odpowiedzi na katastrofę zniszczenia Drugiej Świątyni Jerozolimskiej i niewoli babilońskiej. Zmagający się z konsekwencjami tej samej tragedii autor Księgi Lamentacji odrzuca grzech i karę jako wyjaśnienie $^{10}$. Również w rabinicznej tradycji widoczny jest ambiwalentny stosunek do

${ }^{9}$ Zob. Adam Gregerman, Building on the Ruins of the Temple: Apologetics and Polemics in Early Christianity and Rabbinic Judaism, Tübingen: Mohr Siebeck, 2016; Joel S. Kaminsky, Corporate Responsibility in the Hebrew Bible, Sheffield: Sheffield Academic Press, 1995 („Journal for the Study of the Old Testament Supplement", t. 196).

${ }^{10}$ Księga Lamentacji bardzo długo była interpretowana jako jednoznaczna afirmacja teodycei grzechu i kary, co wynikało m.in. z przypisania autorstwa poematu Jeremiaszowi. Na ten temat zob. Alan Cooper, The Message of Lamentations, ,Journal of the Ancient Near Eastern Society" 2001, t. 28, nr 1, s. 1-18. Zob. także: Tod Linafelt, Surviving Lamentations: Catastrophe, Lament, and Protest in the Afterlife of a Biblical Book, Chicago and London: Chicago University Press, 2000, s. 35-61; Alan Mintz, Hurban: Responses to Catastrophe in Hebrew Literature, Syracuse, NY: Syracuse University Press, 1996, s. 17-48; F.W. Dobbs-Allsopp, Weep, O Daughter of Zion: A Study of the City Lament Genre in the Hebrew Bible, Rome: Editrice Pontificio Instituto Biblico, 1993; idem, Tragedy, Tradition and Theology in the Book of Lamentations, „Journal for the Study of the Old Testament" 1997, t. 22, nr 74, s. 29-60; Claus Westermann, Lamentations: Issues and Interpretation, Minneapolis: Augsburg Fortress, 1994; Ian Provan, Lamentations, New Century Bible Commentary, Grand Rapids: Eerdman's Press, 1991; Johan Rankema, Theodicy in Lamentations? [w:] Theodicy in the Word of the Bible, red. Johannes Cornelis de Moor, Leiden: Brill, 2003, s. 410-428. Bardzo ciekawym przykładem odrzucenia teodycei grzechu i kary jest 20 rozdział Księgi Ezechiela, szczególnie w zestawieniu z jednoznaczną obroną sprawiedliwości boskich wyroków w rozdziale 18. Księga Hioba jest często przedstawiana jako najbardziej wyrazisty przykład zakwestionowania tego schematu wyjaśnienia. Należy jednak podkreślić, że autorzy Księgi Hioba byli zainteresowani cierpieniem indywidualnym, a nie zbiorowym. Teodycea deuteronomiczna dotyczy zaś tego drugiego. Z tego względu Księga Hioba jest nie tyle zanegowaniem teodycei deuteronomicznej, ile raczej odpowiedzią na zupełnie inne pytanie, na co zwraca uwagę Gregerman. Co do tego, jakiej odpowiedzi Księga Hioba ostatecznie udziela, opinie są podzielone. W tradycji rabinicznej dominuje interpreta- 
retrybutywnej teodycei, która stawała pod znakiem zapytania, ilekroć cierpienie wydawało się niewspółmierne z grzechem postrzeganym jako jego przyczyna. Znakomitym tego przykładem jest midrasz Ejcha Rabba, rabiniczny komentarz do Księgi Lamentacji z V w.

Jednym z uderzających aspektów Lamentacji jest to, że jakkolwiek ich autor stwierdza, iż Jerozolima „ciężko zgrzeszyła, stąd budzi odrazę”, a w „fałdach jej sukni plugastwo" (Lm 1:8-9), to jednak nigdzie nie wyjaśnia, za jaki grzech miasto zostało pokarane zniszczeniem. Na tle poetyckiego opisu udręki miasta i jego mieszkańców wyznania winy są blade i nieprzekonujące. Wydają się raczej refleksem zwyczajowej pobożności lub regułą gatunku literackiego niż wiarygodnym wyjaśnieniem przyczyn tragedii. Na pierwszy rzut oka midrasz Ejcha Rabba przedstawia sprawy w diametralnie odmienny sposób. Zamiast mglistych wyznań nieokreślonego bliżej grzechu w Ejcha Rabba znajdujemy szczegółowe listy popełnionych wykroczeń. „Wygnańcem jest Juda przez nędzę”, stwierdza autor Lamentacji (1:3). W rabinicznej interpretacji czytamy:

„Przez nędzę”. Ponieważ jedli zakwas w czasie Pesach wbrew nakazowi „Nie będziesz jadł chleba zakwaszonego” (Pwt 16:3). Inna interpretacja „przez nędzę": ponieważ wzięli zastaw biedaka, wbrew słowom „Wszakże jeśli to jest człowiek ubogi, nie położysz się spać [nakryty] tym zastawem" (Pwt 24:12). Inna interpretacja [...]: ponieważ niesprawiedliwie gnębili najemników w zapłacie wbrew temu, co jest powiedziane: „Nie będziesz niesprawiedliwie gnębił najemnika ubogiego i nędznego" (Pwt 24:14). [...] ponieważ okradli biedaków z tego, co im się należało, wbrew temu, co jest powiedziane: „[Nie będziesz ogołacał winnicy i nie będziesz zbierał tego, co spadło na ziemię w winnicy.] Zostawisz to dla ubogiego i dla przybysza" (Kpł 19:10). [...] ponieważ oddawali cześć bożkom [...] $]^{11}$.

Czternaście z trzydziestu sześciu proemów do Ejcha Rabba kończy się słowami: „ponieważ zgrzeszyli, zostali wygnani”. Skala zniszczenia domagała się grzechu o monstrualnych proporcjach i rabiniczny komentarz do Księgi Lamentacji nie pozostawia wątpliwości, że takie grzechy zostały popełnione. Za pomocą hiperboli rabini w Ejcha Rabba nakreślili obraz Judy, której mieszkańcy odrzucili wszystkie prawa Tory i składali dzieci w ofierze obcym bożkom ${ }^{12}$. Z perspektywy reguł rządzących przymierzem między Bogiem a Izraelem trudno wyobrazić sobie większe przestępstwa. I to właśnie obrona tych reguł - przede wszystkim podstawowej przesłanki łączącej narodowe kataklizmy z grzechem i karą - jest w znacznej mierze celem autorów Ejcha Rabba ${ }^{13}$.

cja, że Hiob nie sprostał próbie, której został poddany. Zob. np. Mark Larrimore, The Book of "Job": A Biography, Princeton: Princeton University Press, 2013.

${ }^{11}$ Midrash Rabbah: Lamentations, tłum. A. Cohen, London: Soncino Press, 1951, I.3:28.

${ }^{12}$ Ibidem, I.1:1, I.9:36.

${ }^{13}$ W przeszłości dominujące odczytanie Ejcha Rabba podążało tropem wyznaczonym przez interpretację samej Księgi Lamentacji jako jednoznacznie stosującej model winy i kary. 
Nie oznacza to jednak, że byli oni całkowicie wolni od wątpliwości. W tym samym midraszu znajdujemy opisy Boga owładniętego irracjonalną pasją, a także Boga pogrążonego w głębokiej rozpaczy i opłakującego zniszczenie Jerozoli$\mathrm{my}^{14}$. W dramatycznie nakreślonej scenie sądu nad Jerozolimą miasto w obronę bierze sam Abraham, a przywołana w roli świadka oskarżenia Tora stoi w milczeniu $^{15}$. W szczególnie uderzającej scenie rabini zdają się kwestionować jakikolwiek związek między katastrofą, która dotknęła Judę, a zachowaniem jej mieszkańców:

Żyd przeszedł przed cesarzem Hadrianem i pozdrowił go. Król zapytał: „Kim jesteś?”. Odpowiedział: „Jestem Żydem”. [Cesarz] wykrzyknął: „Jak śmie Żyd przejść przed Hadrianem i go pozdrowić!!" Rozkazał: „Zabierzcie go i zetnijcie mu głowę". Inny Żyd przechodził i widząc, co stało się z pierwszym mężczyzną, nie pozdrowił go. Król zapytał: „Kim jesteś?”. Ten odpowiedział: „Jestem Żydem”. [Cesarz] zakrzyknął: „Jak śmie Żyd przejść przed Hadrianem i nie pozdrowić go!”. Rozkazał: „Zabierzcie go i zetnijcie mu głowę”. Jego senatorzy rzekli: „Nie możemy pojąć twoich uczynków. Ten, który cię pozdrowił, został zabity, i ten, który cię nie pozdrowił, został zabity!”. Odpowiedział: „Chcecie mi radzić, jak mam zabijać tych, których nienawidzę!"16.

W Biblii oraz w tradycji rabinicznej teodycea i antyteodycea współistnieją ${ }^{17}$. Nie ulega wątpliwości, że w rywalizacji między usprawiedliwieniem i odmową usprawiedliwienia boskich wyroków ostatecznym zwycięzcą stała się teodycea. Dobitnie świadczy o tym włączenie cytowanego wcześniej fragmentu Księgi Powtórzonego Prawa do modlitwy Szema, jak również znajdujące się w liturgii na dni świąteczne stwierdzenie mipnej chatenu galinu me-arcenu („za nasze grzechy zostaliśmy wypędzeni z naszej ziemi"). Formuła mipnej chatenu stała się dominującym wyjaśnieniem narodowych katastrof w żydowskiej historii. W tym kontekście nie dziwi, że była to pierwsza odpowiedź, po którą sięgnął Szlomo

Znakomitym tego przykładem jest: Jacob Neunser, The Midrash Compilations of the Sixth and Seventh Centuries, t. 1: Lamentations Rabbah, Atlanta, GA: Scholars Press, 1989. Podobne odczytanie proponuje David Kraemer, Responses to Suffering in Classical Rabbinical Literature, New York: Oxford University Press, 1995. Linafelt poddaje ją bardzo wnikliwej i przekonywającej krytyce w Surviving Lamentations. Zob. także: Mintz, Hurban ...; Shaye J.D. Cohen, The Destruction: From Scripture to Midrash, „Prooftexts” 1982, t. 2, nr 1; Gregerman, Building on the Ruins...; David Stern, Parables in Midrash: Narrative and Exegesis in Rabbinic Literature, Cambridge, MA: Harvard University Press, 1991; idem, Imitatio Hominis: Anthropomorphism and the Characters of God in Rabbinic Literature, „Prooftexts” 1992, t. 12, nr 2.

${ }^{14}$ Midrash Rabbah: Lamentations..., proem 5.

${ }^{15}$ Ibidem, proem 24.

${ }^{16}$ Ibidem, III.58.

${ }^{17}$ Zob. Zachary Braiterman, (God) After Auschwitz: Tradition and Change in Post-Holocaust Jewish Thought, Princeton, NJ: Princeton University Press, 1998; N.N. Trakakis, Anti-Theodicy [w:] The Cambridge Companion to the Problem of Evil, red. Chad Meister, Paul J. Moser, New York: Cambridge University Press, 2017, s. 124-143. 
Zalman Unsdorfer. W jego rozważaniach odzwierciedla się także obecna w tradycji rabinicznej ambiwalencja.

\section{„U Ciebie, Panie, sprawiedliwość, a u nas wstyd na twarzach”}

W ostatnim tygodniu grudnia $1941 \mathrm{r}$. dramatyczne wydarzenie wstrząsnęło społecznością bratysławskich Żydów. W krótkiej notce na marginesie kazania przygotowanego na 3 stycznia 1942 r. Unsdorfer zapisał: „W tym tygodniu dom starców w Patronce, gdzie kilka dni wcześniej zgromadzono starsze osoby, został doszczętnie spalony. Starcy w wielkiej trwodze i zamieszaniu zebrali się w holu jadalnym" ${ }^{18}$. Powściągliwe słowa Unsdorfera stały w sprzeczności z ogromem tragedii, która rzuciła głęboki cień na jego kazanie:

Panie wszechświata, zgrzeszyliśmy i czyniliśmy zło. Sprawiedliwość jest z Tobą i nie ma niesprawiedliwości w sprawiedliwym i prawym. Miarka za miarkę. Ale czy naprawdę zgrzeszyliśmy tak bardzo, że skazałeś starych ludzi na płomienie i panikę? Panie wszechświata, niech niebiosa nie dopuszczą, byśmy kwestionowali Twoją naturę i sprawiedliwość Twoich wyroków. Ale błagamy, byś był miłosierny jak ojciec względem swoich dzieci. Miej miłosierdzie nad nami z Twego wielkiego miłosierdzia i z miłości, którą masz dla świata i którą nas ukochałeś ${ }^{19}$.

W słowach Unsdorfera pobrzmiewa echo pieśni Mojżesza: „Potężny, którego dzieła są doskonałe, bo wszystkie jego drogi są prawością. Bóg ufności, bez niesprawiedliwości. Przekupstwo nie jego, to skaza jego synów - pokolenia przewrotnych i wypaczonych" (Pwt 32:4-5). Boska sprawiedliwość i prawość są aksjomatyczne. Równie pewna jest nieprawość po stronie ludzkiego uczestnika przymierza. Jeżeli wszystkie drogi Boga są słuszne, źródłem nieprawości musi być człowiek. Wątpliwości nie podlega również aktywność Boga w historii. Ludzki grzech prowokuje boską odpowiedź punitywną. Pozostaje jednak pytanie o adekwatność kary. Za jakie grzechy karą mogłaby być śmierć w płomieniach? Na to pytanie Unsdorfer nie potrafił odpowiedzieć. W swoich kazaniach Unsdorfer próbował przedstawiać taką interpretację cierpienia, która nie stałaby w sprzeczności z logiką przymierza i tradycyjną odpowiedzią na pytanie o naturę i źródła cierpienia. Czasem pytania i błagania biorą jednak górę nad wytłumaczeniami. 12 marca 1942 r. Unsdorfer pytał:

Czego od nas chcesz? Pokuty i wyznania grzechów? Wyznajemy je i powracamy do Ciebie: zgrzeszyliśmy, dopuszczaliśmy się występku, czyniliśmy zło. Rozbitego ducha? Patrz na nasze dusze złamane cierpieniem. Chcesz dobroczynności? Patrz, dajemy cedakę. Błagamy, nie bądź na nas zbyt gniewny. Co da nasza krew, jeśli ją rozlejesz?

\footnotetext{
${ }^{18}$ Siftej Szlomo..., s. 81.

${ }^{19}$ Ibidem, s. 88.
} 
Źródłem tych pytań było głębokie cierpienie. W kazaniu poprzedza je jednak jednoznaczna afirmacja: „We wszystkim, co nas spotyka, jesteś sprawiedliwy. Ty jesteś wybawicielem Izraela, Twoja świętość jest wieczna"20.

Zwracając się do zgromadzonych w synagodze wiernych 3 stycznia 1943 r., Unsdorfer zaczął od przeprosin: „Ku memu wielkiemu żalowi moja głowa i serce nie były gotowe do tego, by przyszykować kazanie takim, jakie powinno ono być dla tak szlachetnego zgromadzenia. A to z powodu udręczenia niewolą”21. „Biada mi, jeśli będę mówił! Biada mi, jeśli będę milczeć!”22, kontynuował. Mimo udręki cierpiącego ducha mówił dalej: „Być może jest naszym obowiązkiem, byśmy przebudzili się co do dziejących się wydarzeń, co do złowrogich dekretów, które powtarzają się każdego dnia, [żebyśmy dostrzegli, że] «u Ciebie, Panie, sprawiedliwość, a u nas wstyd na twarzach» (Dn 9:7). Wiele spośród złowrogich wyroków, które widzimy na własne oczy, przychodzi miarka za miarkę"23. Żydzi nie dawali wystarczająco wiele na cele dobroczynne i woleli trzymać swoje oszczędności w bankach. Teraz nowe dekrety zakazują im pobrać pieniądze z banku, nawet gdyby chcieli to zrobić. Żydom nie wolno wychodzić z domu w wigilię Nowego Roku. Dlaczego? „Przez nasze liczne grzechy, w czasach pokoju my także świętowaliśmy i radowaliśmy się wedle kalendarza narodów"24, odpowiedział Unsdorfer. Podobnie, kontynuował, dawniej Żydzi korzystali ze świeckiej edukacji i z nowoczesnych środków komunikacji. Dziś szkoły są zamknięte, a Żydom nie wolno nawet mieć w domu radia. Ubój rytualny został zakazany, gdyż przed wojną Żydzi kupowali i spożywali niekoszerne jedzenie.

Kazali nam nosić żółte łaty, żeby ogłosić, że jesteśmy Żydami. Przez nasze grzechy, wstydziliśmy się naszych żydowskich ubrań i imion, naszych cicit i mezuz na naszych drzwiach, kiedy było to naszym przykazaniem, żeby wszyscy, którzy na nas patrzyli, wiedzieli, że jesteśmy nasieniem błogosławionego Boga. [...] Dziś przeciwnie, wrogowie zadekretowali, że każdy ma w nas rozpoznać Żydów. Więc kazali w oknie każdego naszego sklepu umieścić wyraźny znak, że to jest żydowski sklep ${ }^{25}$.

W tym kazaniu Unsdorfer przedstawił szczegółową listę występków, jakich Żydzi dopuścili się względem zobowiązań wypływających z przymierza, oraz represji, które służyły jako zadośćuczynienie za grzechy. Sankcje wprowadzone w życie przez pronazistowski rząd Słowacji nie były dla Unsdorfera jedynie zarządzeniami stworzonymi przez władze po to, aby dodatkowo utrudnić życie słowackich Żydów. Postrzegał je raczej z perspektywy dynamiki określonej przez warunki przymierza pomiędzy Bogiem a Izraelem - jako odpowiedzi na

\footnotetext{
${ }^{20}$ Ibidem, s. $128-129$.

${ }^{21}$ Ibidem, s. 81.

${ }^{22}$ Ibidem, s. 86.

${ }^{23}$ Ibidem.

${ }^{24}$ Ibidem.

${ }^{25}$ Siftej Szlomo..., s. 87.
} 
zachowania niezgodne z tymi warunkami. Odpowiedzi, których źródłem w ostatecznym rozrachunku był Bóg. $W$ ten sposób prześladowania zostały wyjęte $\mathrm{z}$ ich kontekstu politycznego i nacechowane znaczeniem wykraczającym poza bezpośrednie okoliczności. Nie znaczy to, że Unsdorfer nie miał wątpliwości, czy kara spotykająca Izrael jest odpowiednia do popełnionych występków. „Wiele spośród złowrogich wyroków, które widzimy na własne oczy", mówił w kazaniu, „jest miarką za miarkę”. Wiele, ale nie wszystkie. Czy spalenie żywcem chorych i starców mogło być karą? Cierpienie spotykające niewinnych zadawało kłam dominującemu wytłumaczeniu. Jak autor Księgi Lamentacji i jak rabini, których rozmowy zostały zapisane w midraszu Ejcha Rabba, Unsdorfer oscylował między afirmacją a wątpieniem.

W reakcji na przedwojenne regulacje utrudniające życie żydowskiej społeczności Bratysławy Unsdorfer z przekonaniem stwierdzał, że „wszystko to przychodzi do nas z niebios jako upomnienie i przestroga, byśmy ulepszyli nasze uczynki, wyznali nasze grzechy i naprostowali nasze ścieżki" ${ }^{26}$. To podstawowe rozumienie nie zmieniło się z upływem czasu. W komentarzu do traktatu Pirkej Awot Unsdorfer cytował słowa, które Juda odniósł do swojej córki Tamar - „ona jest sprawiedliwsza ode mnie" (Rdz 38:26) - i potraktował je jako odnoszące się do Boga: Żydzi zawsze muszą usprawiedliwiać boskie wyroki, gdyż Bóg jest sprawiedliwy, a „nasz jest wstyd” ${ }^{27}$. Bóg nie wymierza kary niesprawiedliwie ${ }^{28}$, a zatem wina musi być wskazana, by ramy przymierza mogły pozostać nienaruszone. Wedle Talmudu:

[...] jeśli ktoś widzi, że dotykają go cierpienia, niech zastanowi się nad swoimi uczynkami, jak powiedziano: „Rozważmy, oceńmy swe drogi, powróćmy do Pana" (Lm 3:40). Jeśli nie znajdzie żadnego grzechu [za który zasługiwałby na cierpienie], gdy rozważy swoje uczynki, niech przypisze je [swoje cierpienia] grzechowi zaniedbania Tory, jak napisano: „Szczęśliwy mąż, którego karcisz, Boże, i prawem Twoim pouczasz". (Ps 94:12) ${ }^{29}$

Zarówno Biblia, jak i Talmud nie wykluczają możliwości niezasłużonego cierpienia. Klasyczne teksty żydowskie dostatecznie wspierają jednak teodyceę przymierza i w konsekwencji umożliwiają traktowanie przypadków, gdy związek między cierpieniem a grzechem nie może być wskazany, jako niewytłumaczalnych anomalii, jako tymczasowych zaburzeń obowiązującego porządku moralnego - są to wyjątki, a nie reguły. Reguły są jednoznaczne i łączą cierpienie $\mathrm{z}$ grzechem.

Sam związek między cierpieniem a grzechem nie jest jednak dostateczny. Grzech może być bezpośrednią przyczyną, ale sam w sobie nie wskazuje na żaden cel i w konsekwencji nie jest wystarczający do tego, by cierpieniu nadać

\footnotetext{
${ }^{26}$ Ibidem s. 305.

${ }^{27}$ Ibidem, s. 284.

${ }^{28}$ Talmud Babiloński, edycja wileńska, Berachot $5 b$.

${ }^{29}$ Ibidem, 5 a-b.
} 
konstruktywny sens. Aby być sensowne, cierpienie musi służyć jakiemuś celowi. Teodycea przymierza zapewnia celowość cierpienia przez związek między cierpieniem jako karą a skruchą i oczyszczeniem. W tym kontekście nie zaskakuje, że w kazaniu z 3 stycznia 1943 r. Unsdorfer z aprobatą przywołał częstokroć cytowane zdanie z talmudycznego traktatu Berachot: „z pewnością cierpienie oczyszcza z grzechów"30. Unsdorfer powracał do tej idei wielokrotnie. W komentarzu do Pirkej Awot argumentował, że oczyszczenie i skrucha są celem cierpienia $^{31}$. Kłopoty i ból są darem od Boga, który chce usunąć najmniejsze ślady skażenia ze swojego skarbu - narodu żydowskiego - i w ten sposób przywrócić go do stanu pierwotnej czystości i bliskości z boską rzeczywistością ${ }^{32}$. Bóg wymaga więcej od nas, zadeklarował Unsdorfer, ponieważ ,jesteśmy dziećmi narodu wybranego”, a Bóg „karci tych, których kocha” ${ }^{33}$. W ten sposób rabin ustanawiał związek między cierpieniem, oczyszczeniem i miłością Boga. Cierpienie zawsze jest zasłużone, ale nawet jeśli jest ono karą, można je postrzegać jako isurim szel ahawa, jako znak bożej miłości, a nie boskiego gniewu. Bóg karze, dlatego że kocha. Kara nie jest celem samym w sobie, lecz wezwaniem do skruchy i tym samym krokiem na drodze do pojednania. Cierpienie przychodzi, abyśmy mogli przybliżyć się do Boga, zapewniał Unsdorfer ${ }^{34}$. Innymi słowy, co może wydawać się wyrazem boskiego atrybutu sądzenia, jest przejawem atrybutu miłosierdzia. W ostatecznym rozrachunku są one jednością i ich rozróżnianie wynika wyłącznie z ograniczonego charakteru ludzkiego postrzegania ${ }^{35}$.

Cierpienie niewinnych nie może być jednak wytłumaczone. W święto Jom Kipur, 9 października 1943 r., Unsdorfer prosił:

Władco świata! [...] Znasz wszystkie nasze trudności. Nie mamy słów, by opisać je wszystkie, ale wszystko jest jawne dla Ciebie. Tak wiele pobożnych mężczyzn i kobiet zostało zamordowanych. Uczeni, starcy, młodzi, chłopcy. Wszyscy zostali zabrani ze swoich domów, by złożyć dusze w ofierze uświęcającej boskie imię. Mędrcy pytali: dlaczego wspominamy śmierć dzieci Aarona w Jom Kipur? Abyśmy wiedzieli, że również Aaron pokutował (Joma 53a). Jak wielu zamordowanych nie mogło znieść trudności i umarło po drodze? „Ziemio, nie zakryj mej krwi, by krzyk ukojenia nie zaznał” (Hi 16:18), dopóki Bóg nie spojrzy z niebios i nie pomści swojego narodu i swojej Tory. Pamiętaj te ofiary, wejrzyj na ofiarowanie Izaaka i przynieś pocieszenie. Poskrom swój gniew, połóż kres zbrodni i zagładzie swojego narodu i miej litość nad jego resztką ${ }^{36}$.

\footnotetext{
${ }^{30}$ Ibidem, 5a; Siftej Szlomo..., s. 86.

${ }^{31}$ Siftej Szlomo..., s. 182.

${ }^{32}$ Ibidem, s. 227.

${ }^{33}$ Ibidem, s. 226; Pwt 8:5: „Rozważaj więc w twoim sercu, że tak jak człowiek uczy swojego syna, tak samo Bóg, Pan twój, uczy ciebie".

${ }^{34}$ Siftej Szlomo..., s. 280.

${ }^{35}$ Ibidem, s. 57, por. także ibidem, s. 85, 88, 90.

${ }^{36}$ Ibidem, s. 156.
} 
W święto Rosz ha-Szana, 22 września 1941 r., w kazaniu Unsdorfera znalazła wyraz jego całkowita bezsilność:

Nie wiemy, co robić, co Ci powiedzieć, jak Cię ułagodzić, jak ukoić Twój gniew i pragnienie, byśmy uczynili teszuwę [...]. W tak strasznym czasie to nie jest możliwe. Nasze dusze są złamane, jesteśmy znękani [...]. Pragniemy zbliżyć się do Ciebie i oddawać Ci cześć, ale nie ma w nas siły ${ }^{37}$.

Kontynuując kazanie, Unsdorfer wyraził wątpliwości co do tego, czy kara $\mathrm{z}$ niebios była właściwa względem popełnionych występków ${ }^{38}$. Zarówno związek cierpienia z grzechem i karą, jak i z oczyszczeniem jako znakiem boskiej miłości okazały się niewystarczające.

Wątpliwości zrodzone z natury obserwowanego cierpienia nie doprowadziły Unsdorfera do buntu przeciw przymierzu, ale raczej ku milczeniu, które wypełniało pełne nadziei oczekiwanie. Źródłem nadziei było samo przymierze. Pakt pomiędzy Izraelem a Bogiem z jednej strony nakłada na Izrael brzemię rozlicznych obowiązków i groźbę nieszczęść, które mogą spotkać naród żydowski, jeśli nie dotrzyma on swoich zobowiązań. Z drugiej jednak strony ramy przymierza czynią niepodważalny aksjomat $\mathrm{z}$ boskiego zaangażowania $\mathrm{w}$ historię Izraela i z ostatecznego zbawienia.

\section{Wszystko przychodzi z niebios}

Opatrzność, boskie zaangażowanie w historię jest fundamentem myślenia Unsdorfera, który wielokrotnie z niezachwianą pewnością wyrażał przekonanie, że historia toczy się pod boską kontrolą. 20 grudnia 1941 r. apelował: „I przede wszystkim nie poddawajcie się rozpaczy, Boże broń. Nie traćcie ducha i ufności. Bo każda chwila jest ustanowiona w wyższej opatrzności i przyjdzie czas, kiedy ciemność się skończy”39. Rok później, 3 stycznia 1942 r., napisał: „W przyszłości wzmoże się radość i zapomnimy o dniach udręki. Teraz jednak żyjemy w czasie straszliwej próby. Boże broń, byśmy zapomnieli, że wszystko jest pod kontrolą boskiej opatrzności z niebios" ${ }^{40}$. W szabat ha-gadol, 28 marca 1942 r., Unsdorfer przywołał nazwę tradycyjnego posiłku pesachowego - sederu - by ponownie odnieść się do tej kwestii: „Ta święta noc nazywa się seder (porządek), ponieważ ta noc i wszystkie kłopoty, wszystkie złowrogie dekrety, Boże broń, a także odkupienie i zbawienie, które następowały w przeszłości i które wydarzą się w przyszłości - wszystko to należy do porządku. Tego chce i to czyni dla nas Święty Jedyny, niech będzie błogosławiony"41.

\footnotetext{
${ }^{37}$ Ibidem, s. 151.

${ }^{38}$ Ibidem, s. 153-154, 74, 84.

${ }^{39}$ Ibidem, s. 75.

${ }^{40}$ Ibidem, s. 84.

${ }^{41}$ Ibidem, s. 132.
} 
Obecność Boga w historii nie podlegała wątpliwości, ale dostrzeżenie jej - przyznawał Unsdorfer - wymagało wiary i ufności. Boska obecność nie jest oczywista i może być dostrzeżona tylko z perspektywy wiary:

Wspomina o tym Talmud: „Jeśli rano pominiesz modlitwę «Prawdziwy i stały» i wieczorem modlitwę «Prawdziwy i godny ufności», to nie wypełniłeś przykazania. Jest bowiem napisane: «głosić z rana Twoją łaskawość, a wierność Twoją nocami» (Ps 92:3). Noc nawiązuje do ciemności wygnania. Rano nawiązuje do odkupienia. Jeżeli w czasie trudnym naprawdę wierzymy, że wszystko przychodzi z Niebios i jest dla naszego dobra, wówczas zasługujemy na to, by ujrzeć «prawdziwy i stały», by ujrzeć objawioną «z rana Twoją łaskawość». Ale warunkiem jest «wierność Twoja nocami»" ${ }^{2}$.

Rozważając słowa Jakuba: „Anioł, który wybawił mnie od wszelkiego złego” (Rdz 48:16), Unsdorfer pytał, jak to możliwe, iż Jakub, którego życie było pełne trudności, stwierdził, że był obroniony od wszelkiego zła? Odpowiedź była następująca:

Jakub [naprawdę] powiedział: „Nakażcie swoim sercom, by wiedziały, że nawet kiedy byłem w ogromnych tarapatach, miałem wiarę i zaufanie, że trudności nie będą zupełne, Boże broń. Pośród trudności widziałem światło bożego słowa”. To jest „anioł, który wybawił mnie od wszelkiego złego”. „Anioł” oznacza wiarę w boską opatrzność ${ }^{3}$.

Perspektywę nakreśloną tutaj przez Unsdorfera można nazwać teologicznym i hermeneutycznym kołem podobnym do tego, jakie sformułował św. Anzelm $\mathrm{w}$ formule credo ut intelligam: wiara i zaufanie umożliwiają zrozumienie. Zrozumienie zaś umacnia wiarę. Kluczem do właściwego zrozumienia jest zatem odpowiednia perspektywa. Unsdorfer wyjaśniał za pomocą opowieści o człowieku, który był niezadowolony z zakupionego lustra:

Po kilku dniach mężczyzna przyszedł z powrotem do sklepu. Chciał zwrócić lustro, bo nie było dobre. Widział w nim jedynie pełną gniewu twarz i brzydkie ubrania. Właściciel sklepu wyjaśnił mu, że lustro jest w porządku. Problem był w patrzącym. I w rzeczy samej tu właśnie tkwił defekt. Kiedy patrzymy na tarapaty, które nas otaczają, i brak bożego wpływu, problem nie jest w Bogu, bo zło nigdy nie przychodzi od Niego. Święty Jedyny, niech będzie błogosławiony, ma dla stworzenia wyłącznie dobroć i miłosierdzie. Problem jest po stronie odbiorców, który nie widzą i nie zasługują na całą tę dobroć i miłosierdzie ${ }^{44}$.

Cierpienie nie oszczędza ludzi głębokiej wiary. Ich egzystencjalna postawa wiary i zaufania głęboko przeobraża jednak to, w jaki sposób postrzegają oni

\footnotetext{
${ }^{42}$ Ibidem.

${ }^{43}$ Siftej Szlomo..., s. 84.

${ }^{44}$ Ibidem, s. 305.
} 
rzeczywistość. W komentarzu do Pirkej Awot Unsdorfer cytuje następujący fragment Talmudu:

Rabbi Samuel ben Nachmani powiedział, że Rabbi Jochanan rzekł: Nieszczęście przychodzi na świat, kiedy są w nim źli ludzie i zawsze najpierw dotyka sprawiedliwych, jak jest napisane: „jeśli powstanie ogień i ogarnie ciernie” (Wj 22:6). Kiedy powstaje ogień? Tylko jeśli w pobliżu są ciernie. Ale zaczyna się zawsze od sprawiedliwych, jak jest powiedziane, tak że spaliła się sterta zboża. Nie „i spaliłaby się sterta zboża”, ale „tak że spaliła się sterta zboża”, co znaczy, że „sterta zboża” już się spaliła ${ }^{45}$.

Unsdorfer przywołał ten fragment także w kazaniu na Rosz ha-Szana 12 września 1942 r. Wydaje się, że sprawiedliwi i nikczemni cierpią tak samo zauważył. Jest jednak między nimi zasadnicza różnica:

Sprawiedliwi nie doznają udręki, ponieważ dla nich wypełnianie bożej woli nie jest cierpieniem [...]. Jak powiedziano: „szukającym Boga żadnego dobra nie zabraknie" (Ps 34:10), co znaczy, że nie odczuwają braku, ponieważ wszystko jest dla nich dobre. I choć może się czasem wydawać, że czegoś im brak, bo nie mają chleba, bo ich domy są puste, a ubrania znoszone, ich serca się radują i nie odczuwają tych braków w ogóle. Jest tak dlatego, że ich serca są zawsze zwrócone ku Bogu i Torze i nie ma w nich zmartwień [...]. Są pełni wdzięczności za wszystko, co Bóg im odmierza, i ufają głęboko w Boga, że wszystko jest dla ich dobra i że od Niego nie przychodzi nic złego ${ }^{46}$.

Nawet wiara i ufność nie dają jednak całkowitego zrozumienia, które jest niemożliwe ze względu na ontologiczną różnicę między Bogiem a człowiekiem. W jaki sposób ograniczone, ucieleśnione i schwytane w pułapkę czasu stworzenie może $w$ pełni pojąć działania nieskończonego bytu znajdującego się poza czasem? Bóg jest wieczny, mówi Unsdorfer, i z tego powodu nigdy nie będziemy w stanie w pełni zrozumieć jego działań w historii ${ }^{47}$. Żydzi mogą i muszą ufać w to, że Bóg jest obecny poza wydarzeniami, których doświadczają, i poza cierpieniem, które znoszą, wiedząc, że „przyjdzie czas, kiedy zobaczymy, że to wszystko jest dla naszego dobra", stwierdził Unsdorfer w kazaniu z 7 marca $1942 \mathrm{r}^{48}$ Rozwijając temat, nawiązał do rozróżnienia przykazań racjonalnych i objawionych ${ }^{49}$. Biblijne przykazanie złożenia ofiary z czerwonej krowy (Lb 19:1-10) jest przykładem drugiego rodzaju. Żydzi akceptują to przykazanie wraz z całym przymierzem z miłością, stwierdza Unsdorfer, nie zadając pytań, nie domagając się uzasadnień. Prześladowania powinny być przyjęte w taki sam sposób:

\footnotetext{
${ }^{45}$ TB, Baba Kama 60a; Siftej Szlomo..., s. 244; por. ibidem, s. 141.

${ }^{46}$ Ibidem, s. 265.

${ }^{47}$ Ibidem, s. 145.

${ }^{48}$ Ibidem, s. 117.

${ }^{49}$ Rozróżnienie to sformułował po raz pierwszy, pod wpływem islamu, Saadia Gaon w Sefer Emunot we-Deot III.2. Zob. np. Isaac Heinemann, The Reasons for Commandments in Jewish Thought from the Bible to the Renaissance, Boston: Academic Studies Press, 2008.
} 
Nie pytamy, nie zadajemy pytań, a jedynie przestrzegamy przykazań z radością. Czynimy wolę naszego ojca w niebiosach, który dał nam Torę dla naszego dobra, aby nas unieść i ulepszyć. Jesteśmy przyzwyczajeni do tego, by przyjmować i przestrzegać boskich przykazań bez uzasadnienia, w miłości i z pełną wiarą. I tak samo, kiedy dotykają nas złowrogie dekrety, kiedy dręczy nas ucisk, nie powinniśmy zadawać pytań, rozmyślać o naturze Boga, ponieważ moje myśli nie są waszymi, mówi Bóg. Nasi mędrcy uczyli: „Ustanowiłem prawo! Wydałem dekret! Nie wolno Ci się nad nimi głowić!"50.

Docierając do granicy możliwych wyjaśnień, Unsdorfer uciekł się do egzystencjalnej postawy wiary i ufności. Boskie zarządzenia nie zawsze mogą być zrozumiane, ale zawsze muszą być zaakceptowane. Czasem zrozumienie może przyjść dopiero post factum, stwierdza Unsdorfer i przywołuje fragment Księgi Wyjścia: „[Bóg] powiedział: Jest przygotowane miejsce, gdzie staniesz na skale, i stanie się tak, że gdy będzie przechodziła Moja chwała, postawię cię w szczelinie skalnej i osłonię cię Moją ochronną mocą, aż przejdę. Odsunę Moją ochronną moc i zobaczysz Mnie z tyłu, ale Mojej twarzy nie zobaczysz" (Wj 33:21-23) ${ }^{51}$ :

Koniec końców widzimy, że wszystko, co przychodzi od Świętego Jedynego, niech będzie błogosławiony, jest dla naszego dobra. Tylko zawczasu nie możemy tego dostrzec. Przed zdarzeniem nie możemy zobaczyć wszystkiego. Dopiero kiedy ciemność rozświetli się nową jasnością, osiągniemy wizję boskiej opatrzności nad nami ${ }^{52}$.

Innymi słowy, pełne zrozumienie, pewność wiedzy mogą nadejść dopiero z chwilą wybawienia. Do tego momentu wiara i ufność muszą zastąpić zrozumienie. Niezachwiana wiara i ufność, trzeba dodać, ponieważ tutaj Unsdorfer sięga po biblijny wzorzec takiej postawy. Dla rabina życie Abrahama, który taką wiarę właśnie uosabiał, stanowi model, przez który należy patrzeć na dramatyczną sytuację słowackich Żydów.

\section{Maasej awot siman le-banim}

W 1941 i 1942 r. Unsdorfer powracał do dwóch biblijnych opowieści, funkcjonujących w jego kazaniach jako modele, za pośrednictwem których aktualne wydarzenia mogą być umiejscowione w ramach wyznaczonych przez historię przymierza i teodyceę. Dwukrotnie, w kazaniach z 31 października 1941 oraz 7 listopada 1942 r., Unsdorfer przytoczył zdanie z midrasza Tanhuma: Maasej awot siman le-banim - „Uczynki ojców są znakiem dla dzieci”53. W jego kazaniach biblijne opowieści służą jako klucze do interpretacji wydarzeń. Wyjęte $\mathrm{z}$ bezpośredniego tekstualnego kontekstu i przeistoczone $\mathrm{z}$ opowieści w poza-

\footnotetext{
${ }^{50}$ Siftej Szlomo..., s. 118-119.

${ }^{51}$ Zmodyfikowany przekład Pardes Lauder.

${ }^{52}$ Siftej Szlomo..., s. 117.

${ }^{53}$ Ibidem, s. 31, 48; Tanhuma 9.
} 
czasowe wzorce, wedle których rozwija się historia, paradygmaty dostarczyły użytecznych narzędzi do tego, by dramatyczne wydarzenia umieszczać w ramach wyznaczonych przez relację przymierza pomiędzy Izraelem i Bogiem. W tym miejscu przejawia się w kazaniach Unsdorfera wielowiekowa tradycja żydowskiej interpretacji wydarzeń historycznych, którą za Jacobem Neusnerem nazywam myśleniem paradygmatycznym ${ }^{54}$.

W odpowiedzi na pytanie, dlaczego tradycję rabiniczną cechuje zaskakujący dla współczesnego czytelnika brak zainteresowania historią, Neusner przedstawił hipotezę, że rabinów nie interesowała historia w naszym jej rozumieniu, ponieważ dysponowali alternatywnym sposobem porządkowania wydarzeń ${ }^{55}$. Zamiast konstruowania ciągów przyczynowo bądź chronologicznie powiązanych wydarzeń, rabini odnajdowali ich znaczenie przez umiejscawianie ich w wymiarze metahistorycznym. Zamiast koncentrowania się na tym, co jednostkowe i niepowtarzalne, patrzyli na wydarzenia przez pryzmat tego, co powtarzalne. W Biblii rabini znajdowali nie tylko opis tego, jak w zamierzchłej przeszłości rozwijała się relacja między Bogiem i Izraelem, lecz także modele, wzorce, wedle których historia rozwija się zawsze. Na ten sposób myślenia jako charakterystyczny dla żydowskiej tradycji wskazał również Josef Chaim Jeruszalmi (Yosef Hayim Yerushalmi). Oto jeden z opisanych przez niego przykładów: tragedia antyżydowskich pogromów podczas powstania Chmielnickiego w $1648 \mathrm{r}$. domagała się, zdaniem niektórych, liturgicznego upamiętnienia. Jeden z ówczesnych autorytetów żydowskiej społeczności, Jom Tow Lipmann Heller, zgadzał się z tą opinią. Jego zdaniem należało upamiętnić ofiary pogromów. Równocześnie Heller nie widział jednak potrzeby skomponowania specjalnych nowych modlitw. Do upamiętnienia żydowskich ofiar powstania Chmielnickiego w jego przekonaniu powinny służyć modlitwy upamiętniające męczeństwo Żydów zamordowanych w Blois w 1171 r. W uzasadnieniu swojej decyzji Heller stwierdził:

To, co wydarzyło się teraz, podobne jest do dawnych prześladowań, i wszystko to, co przydarzyło się naszym przodkom, przydarzyło się ich potomkom. O sprawach dawnych wcześniejsze pokolenia stworzyły już selihot i opowiedziały o tamtych wydarzeniach. Wszystkie on e stan o wią jedno ${ }^{56}$.

${ }^{54}$ Zob. Barbara Krawcowicz, Paradigmatic Thinking and Holocaust Theology, „,The Journal of Jewish Thought and Philosophy" 2014, t. 22, nr 2, s. 164-189; eadem, History, Metahistory, and Evil: Jewish Theology and the Holocaust, Boston, MA: Academic Studies Press, w druku.

${ }^{55}$ Jacob Neusner, Paradigmatic versus Historical Thinking: The Case of Rabbinic Judaism, „History and Theory” 1997, t. 36, nr 3, s. 353-377 oraz idem, The Idea of History in Rabbinic Judaism, Leiden: Brill, 2004.

${ }^{56}$ Yosef Haiym Yerushalmi, Zachor. Żydowska historia i żydowska pamięć, tłum. Mirosław Wójcik, Warszawa: ŻIH, 2014, s. 80. Skłonność do interpretowania wydarzeń jako przykładów urzeczywistnienia modeli biblijnych została zauważona nie tylko przez Neusnera i Jeruszalmiego. Zob. D.R. Russell, The Method and Message of Jewish Apocalypic, London: SCM Press Ltd, 1964, s. 134-137, 205-212; Michael Fishbane, Revelation and Tradition: Aspects of Inner-Biblical Exegesis, „Journal of Biblical Literature” 1980, t. 99, nr 3, s. 343-361; Isaac Heinemann, 
Maasej awot siman le-banim - wydarzenia z czasów praojców - są znakiem dla ich potomków nie dlatego, że historia jest cykliczna, ale dlatego że toczy się ona wedle dających się rozpoznać wzorców lub paradygmatów, których źródłem jest samo objawienie i które mogą zostać odnalezione w biblijnym tekście.

13 grudnia 1941 r. Unsdorfer napisał, że Żydzi Bratysławy nie tylko czytali odpowiednie części Tory na każdy tydzień, lecz także żyli przez nie. Każdy fragment Tory opisujący próby w życiu Abrahama był trafnym opisem doświadczeń żydowskiej społeczności Bratysławy ${ }^{57}$. W komentarzu do Pirkej Awot Unsdorfer wymienił kluczowe elementy paradygmatu i wydarzenia, które postrzegał jako ich współczesne odpowiedniki:

1. Ur Chaldejskie, kiedy [Abraham] był wrzucony do rozpalonego pieca i uświęcił imię Boga. Bo przez wiele naszych grzechów wiele tysięcy naszych braci w Polsce i w Niemczech zostało złożonych w ofierze uświęcającej imię Boga, zostali zamordowani i spaleni, umarli nienaturalną śmiercią. [...]. 2. „Idź dla siebie z twojego kraju" (Rdz 12:1). My także jesteśmy na wygnaniu, opuszczamy [dom]. Wiele tysięcy naszych braci zostało wygnanych i wędrują z jednego rozproszenia do drugiego. 3. „W ziemi był głód” (Rdz 12:10). 4. „I zabrano jego żonę" (Rdz 12:15). Tak wiele żon oddzielono od mężów i dzieci, jak wiadomo, niech Bóg się zmiłuje. 5. Wojna królów (Rdz 14). My także jesteśmy pośrodku straszliwej wojny i niebezpieczeństwo wisi nad każdą głową jak na polu bitwy, grozi nam siła ognia i nowe rodzaje broni. Niech Bóg ma nas w swojej opiece. 6. Niewolnictwo pod złą władzą. 7. Obrzezanie. My także doświadczamy razów od stóp do głów, boimy się straszliwego bólu i cierpienia. 8. „Abimelek, król Geraru, posłał i zabrał Sarę” (Rdz 20:3). 9. Wygnał matkę i jej dziecko. Nasze dzieci zostały zagnane do obozów do ciężkiej pracy. 10. Ofiarowanie Izaaka. „Dla Ciebie ciągle nas mordują, mają nas za owce na rzeź przeznaczone" (Ps 44:22). My także możemy powiedzieć to, co Chana powiedziała do swoich siedmiu synów: „Moi synowie, idźcie i powiedzcie Abrahamowi, waszemu ojcu, ty przygotowałeś jedną ofiarę, ja przygotowałam siedem" (Gittin 57b) ${ }^{58}$.

Każdy paradygmat jest podwójnie wybiórczy. Po pierwsze, nie zawiera on wszystkich elementów opowieści, lecz jedynie te, które są uznane za istotne. Po drugie, to paradygmat decyduje o tym, które fragmenty rzeczywistości są ważne, a co za tym idzie - realne i znaczące. Paradygmat jako pryzmat, przez który postrzega się rzeczywistość, jest z natury selektywny: nie wszystkie wydarze-

Darchei ha-aggada, Jerusalem: Magnes Press, 1970, s. 32-34; Marc Bregman, Past and Present in Rabbinic Literature, „Hebrew Annual Review” 1978, t. 2, s. 45-59; Joseph Heinemann, The Nature of Aggadah [w:] Midrash as Literature, red. Geoffrey Hartman, Sanford Budick, New Haven: Yale University Press, 1986, s. 41-55; David Roskies, Introduction [w:] The Literature of Destruction. Jewish Responses to Catastrophe, red. David Roskies, Philadelphia: The Jewish Publication Society, 1988; Mintz, Hurban...

${ }^{57}$ Siftej Szlomo..., s. 64.

${ }^{58}$ Ibidem, s. 271-272. 
nia pasują do modelu. To, co do niego nie pasuje, zostaje pozbawione znaczenia, dlatego że to paradygmat jest źródłem znaczenia. Paradygmat nadaje wydarzeniom sens. Wydarzenia pozostające poza jego obrębem ów sens tracą i wtapiają się w niezróżnicowany chaos. W swoich wojennych kazaniach Unsdorfer wplata prześladowania żydowskiej społeczności Bratysławy w historię przymierza poprzez opisanie ich jako realizacji pozaczasowego modelu zakorzenionego w samym objawieniu.

Unsdorfer skoncentrował się na dwóch wydarzeniach z życia Abrahama opuszczeniu rodzimej ziemi i ofiarowaniu Izaaka. 0 deportacjach Żydów z Bratysławy napisał w październiku $1941 \mathrm{r}$ :

Nie pomyśleliśmy, nie wyobrażaliśmy sobie, że i na nas, i na nasze dzieci przyjdzie próba lech lecha ${ }^{59}$. I teraz, w tych dniach, nadeszła. Jesteśmy wypędzani z naszej ojczyzny i z domu naszego ojca [...]. Wielu naszych synów i wielu ubogich członków naszej świętej społeczności zostało wypędzonych do obcej ziemi, do ciężkiej pracy i strasznej udręki ${ }^{60}$.

Nie wiemy, kiedy Unsdorfer zdał sobie sprawę z tego, że wbrew oficjalnym informacjom słowaccy Żydzi byli deportowani nie do obozów pracy, ale do obozów zagłady. Być może to ta wiedza lub podejrzenie sprowokowały go, by w kazaniu z 17 stycznia 1942 r. odwołać się wprost do opowieści o ofiarowaniu Izaaka - przedstawił je jako wydarzenie, które ponownie znalazło urzeczywistnienie w żydowskiej historii ${ }^{61}$. Wedle Unsdorfera, biblijny opis ofiarowania Izaaka to nie tylko trafne odzwierciedlenie aktualnej sytuacji, ale i przykład tego, w jaki sposób Żydzi powinni przyjmować próby, jakie stawia przed nimi Bóg: „I o naszych czasach, o dniu dzisiejszym, parsza Akeda dobrze tłumaczy to, co się dzieje. Mówi ona o mesirat nefesz [ofiarowaniu] synów Izraela zarówno w ich ciałach, jak i dobytku"62. W swoim zachowaniu, w pozbawionej protestu akceptacji boskiej woli Abraham dał przykład mesirat nefesz, ofiarnego oddania własnej duszy Bogu. Teraz, kiedy próba Abrahama ponownie stawała się faktem, urzeczywistniała się również cnota Abrahama:

Skąd przychodzi do nas siła i mocna wiara? Tylko z dziedzictwa naszych przodków. Siła tego starego człowieka, naszego ojca Abrahama, którą pokazał przy próbie, gdy Święty Jedyny, niech będzie błogosławiony, nakazał mu złożyć w ofierze jedynego syna. Abrahama nie opuściła wiara w Boga, który obiecał uczynić jego potomstwo tak licznym jak ziarna piasku i gwiazdy na niebie $^{63}$.

\footnotetext{
${ }^{59}$ Incipit Rdz 12:1, w polskim przekładzie „idź dla siebie”.

${ }^{60}$ Ibidem, s. 31.

${ }^{61}$ Ibidem, s. 41. Unsdorfer powrócił do tego wątku w październiku 1942 r., kiedy wspomniał również o deportacjach „do Polski” (ibidem, s. 32).

${ }^{62}$ Ibidem, s. 42.

${ }^{63}$ Ibidem, s. 41.
} 
Wiara Abrahama była wzorcowa i dziś, przekonywał Unsdorfer, służy ona nie tylko jako wzorzec do naśladowania, lecz także - jako część dziedzictwa patriarchy - jest podstawą i źródłem siły. Abraham był prawdziwie sprawiedliwym człowiekiem, który każdy dzień swojego życia przeżył „w wierze i ufności”:

A temu, kto prawdziwie wierzy w boską opatrzność, nie braknie niczego. Jego kłopoty nie są naprawdę kłopotami, jego śmierć nie jest prawdziwą śmiercią, jego grób nie jest na zawsze. Jest tak dlatego, że sprawiedliwy żyje w wierze, i wszystko, czego chce dla niego Święty Jedyny, niech będzie błogosławiony, jest dobre. Wola Boga jest jego wolą. Sprawiedliwy unicestwia własną wolę przed wolą Świętego Jedynego, niech będzie błogosławiony ${ }^{64}$.

Oprócz opowieści o ofiarowaniu Izaaka szczególnie w latach 1941-1942 Unsdorfer używał biblijnej opowieści o rywalizacji Jakuba i Ezawa jako metahistorycznego paradygmatu: „Wszystko, co spotkało naszego ojca ze strony jego brata Ezawa, zawsze spotyka nas ze strony synów Ezawa"65. Komentując fragment Tory opisujący początek konfliktu między braćmi, Unsdorfer stwierdził:

Tu zaczyna się zło i zbrodnia, które trwają od narodzin Ezawa po nasz dzień. Pokolenie za pokoleniem, z krótkimi momentami wytchnienia, jesteśmy prześladowani i dręczeni przez zło Ezawa po dzień dzisiejszy. I w naszych czasach owo zło wybuchło z większą siłą niż kiedykolwiek od chwili narodzin Ezawa ${ }^{66}$.

Co ciekawe, w tym fragmencie zastosowanie paradygmatu biblijnego do nowych wydarzeń historycznych jest połączone ze świadomością, że tym razem prześladowania, których przedmiotem są Żydzi, są bardziej intensywne niż kiedykolwiek wcześniej. Nowy kontekst historyczny nie osłabia jednak siły paradygmatu. Choć nienawiść i agresja Ezawa osiągnęły nowy poziom intensywności, pozostały one nienawiścią i agresją Ezawa. Innymi słowy, Unsdorfer sięga po

${ }^{64}$ Ibidem, s. 45.

${ }^{65}$ Ibidem, s. 58. Na temat opowieści o Jakubie i Ezawie i jej funkcjonowania jako tego, co nazywam metahistorycznym paradygmatem, zob. Malachi Hacohen, Jacob and Esau: Jewish European History Between Nation and Empire: A Jewish European History, New York: Cambridge University Press, 2019. Zob. także: Gershon D. Cohen, Esau as Symbol in Early Medieval Thought [w:] idem, Studies in the Variety of Rabbinic Cultures, Philadelphia: The Jewish Publication Society, 1991, s. 243-269; Harry Freedman, Jacob and Esau. Their Struggle in the Second Century, „Jewish Bible Quarterly” 1995, t. 23, nr 2, s. 107-115; Gerhard Langer, „Brother Esau?" Esau in Rabbinic Midrash [w:] Encounters of the Children of Abraham from Ancient to Modern Times, red. Antti Laato, Pekka Lindqvist, Leiden: Brill, 2010, s. 75-94; Helen Spurling, The Biblical Symbol of Edom in Jewish Eschatological and Apocalyptic Imagery [w:] Sacred Texts. Explorations in Lexicography, red. Juan Pedro Montferrer-Sela, Angel Urban, Frankfurt am Main: Peter Lang, 2009, s. 271-299; Mireille Hadas-Lebel, Jerusalem against Rome, Leuven: Peeters, 2005, s. 497-512. Na temat identyfikacji chrześcijaństwa z Ezawem i Edomem w tradycji kabalistycznej zob. Elliot R. Wolfson, Venturing Beyond - Law and Morality in Kabbalistic Mysticism, New York: Oxford University Press, 2006, passim.

${ }^{66}$ Siftej Szlomo..., s. 49. 
paradygmatyczną opowieść i w rezultacie nowa sytuacja zostaje płynnie wpleciona w nurt historii przymierza. Świeca pali się najjaśniej, tuż zanim zgaśnie, a ciemność jest najgłębsza tuż przed wschodem słońca, stwierdza Unsdorfer, wyjaśniając zwiększoną intensywność prześladowań ${ }^{67}$. Nienawiść Ezawa osiąga teraz zenit, dlatego że niebawem zostanie zniszczona na zawsze.

Co jest przyczyną periodycznych erupcji nienawiści Ezawa? Wedle Unsdorfera antysemityzm przyjmuje formę przemocy przeciwko Żydom, ilekroć Żydzi przekraczają granice wyznaczone przez przymierze z Bogiem. Kiedy granice oddzielające Żydów od nie-Żydów ulegają zatarciu, budzi się uśpiona nienawiść Ezawa i jego potomków. Żydzi, zauważa Unsdorfer, sprowokowali agresję przeciwko sobie przez przejawy bogactwa, nowoczesny ubiór, uczestnictwo w świeckich aktywnościach, takich jak teatr, sport czy świecka edukacja:

Ezaw kroczy własną drogą. Dlaczego uwikłaliśmy się z nimi? Dlaczego ich drażniliśmy? Święta Tora ostrzegała nas: Oddzielę was od narodów i nie ciesz się, Izraelu, radością narodów [...]. Kiedy jesteśmy w odosobnieniu, w naszych bejt midraszach, kiedy nie próbujemy ich naśladować, zachowywać się jak oni, ubierać się jak oni, studiować ich obcą wiedzę, kiedy pozostajemy od nich oddzieleni - wtedy nie są wobec nas podejrzliwi $[\ldots]^{68}$.

Unsdorfer powraca do tego tematu także w swoim komentarzu do Pirkej Awot, gdy odpowiedzialnością za wybuch antyżydowskiej przemocy obarcza zasymilowanych Żydów, których opisuje jako winnych „wszystkich naszych zgryzot”: „Bo zaprawdę, jeśli synowie naszego narodu pamiętają, że jesteśmy oddzieleni od innych narodów, że naszą dolą jest święta Tora, że jesteśmy skarbem między narodami, wówczas nie ma prześladowań Izraela"69.

Antysemityzm jest zatem skorelowany z zachowaniem Żydów i służy jako narzędzie w ekonomii przymierza. Czy oznacza to, że Unsdorfer akceptował logikę obwiniania ofiary? Naturalnie odpowiedź na to pytanie jest i musi być pozytywna. W ramach systemu, który zakłada, że Bóg jest ostatecznym podmiotem w historii, i który łączy cierpienie z karą, trudno o inne wytłumaczenie antyżydowskiej przemocy.

Jest o nie trudno, ale nie jest to zupełnie niemożliwe. W kazaniu na święto Szawuot, 9 czerwca 1943 r., Unsdorfer przedstawił alternatywną interpretację nienawiści do Żydów, w której antagonizm między potomkami Jakuba i potomkami Ezawa jest zakorzeniony w rywalizacji monoteizmu i bałwochwalstwa: „Od dnia, kiedy Święty Jedyny, niech będzie błogosławiony, dał nam naszą świętą Torę, jesteśmy w stanie wojny z narodami świata, które chcą unicestwić nas, naród Izraela, naród Księgi" ${ }^{70}$. W tym kazaniu Unsdorfer objaśnia antyżydowską przemoc nie jako karę za przekroczenie reguł przymierza, ale wprost przeciw-

\footnotetext{
${ }^{67}$ Ibidem.

${ }^{68}$ Siftej Szlomo..., s. 58-59.

${ }^{69}$ Ibidem, s. 237.

${ }^{70}$ Ibidem, s. 138; TB, Szabat 89b.
} 
nie - jako cenę, którą Żydzi płacą za swoją wierność przymierzu. Tę interpretację można, jak myślę, połączyć z tym, że Unsdorfer ostatecznie porzucił wyjaśnienie prześladowań, których był świadkiem, w kategoriach grzechu i kary. Cierpienie niewinnych nie mogło być wytłumaczone w ten sposób. Ezaw nienawidził Jakuba, ale Jakub nie był temu winny.

Zawarte w Siftej Szlomo kazania, okolicznościowe przemówienia i komentarz do Pirkej Awot to jeden z nielicznych istniejących materiałów umożliwiających nam wgląd $w$ to, $w$ jaki sposób tradycyjna religijna myśl żydowska zmagała się $\mathrm{z}$ fundamentalnymi pytaniami, jakie podsuwała tragiczna rzeczywistość narastających prześladowań. Biorąc pod uwagę to, że przeważającą większość zawartych w Siftej Szlomo tekstów stanowią cotygodniowe kazania przygotowywane przez Unsdorfera dla członków synagogi, której był rabinem, nie sposób zaprzeczyć temu, iż aspekt psychologiczny stanowił najprawdopodobniej ich istotny element. W komentarzu do Pirkej Awot Unsdorfer napisał:

Szczególnie w czasach takich jak te znajdujemy pociechę w tym, że jesteśmy nazwani dziećmi Boga [...]. Jak mówi prorok: „Umiłowałem was - mówi Pan - wy zaś pytacie: W czym się przejawia Twoja miłość? Czyż Ezaw nie był bratem Jakuba? - mówi Pan - A jednak umiłowałem tylko Jakuba. Ezawa zaś miałem w nienawiści" (Ml 1:2-3). Prorok przynosi słowa pociechy narodowi Izraela w czasie udręki i mówi, że Bóg kocha świat i kocha nas miłością ojcowską również w czasie strasznego cierpienia ${ }^{71}$.

Pociechy niesionej w obliczu cierpienia nie sposób lekceważyć. Równocześnie wydaje mi się jednak, że błędem byłoby odczytywanie kazań Unsdorfera i zawartej w nich teologii wyłącznie w kategoriach psychologicznych. W przedstawionej powyżej interpretacji świadomie pominęłam kwestie psychologiczne, by skoncentrować się na teologii i podkreślić, w jak wielkim stopniu ścieżka, którą podczas wojny podążał Unsdorfer, została wydeptana stopami pokoleń myślicieli, którzy przed nim zmagali się z pytaniami o źródła i naturę katastrof spotykających naród żydowski.

W moim odczytaniu wojennych kazań rabina Unsdorfera położyłam silny nacisk właśnie na ten wymiar kontynuacji. Wedle najczęściej bodaj spotykanego rozumienia wpływu Zagłady na teologiczne fundamenty judaizmu podkreśla się jego dramatyzm i skalę. Judaizm po Zagładzie nie może być tym samym judaizmem co wcześniej. Zaistnienie radykalnego zła wstrząsnęło podstawami żydowskiej teologii, których dalsza prawomocność wymagała zmian o równie radykalnej naturze ${ }^{72}$. Wojenne rozważania rabina Unsdorfera sugerują bardziej złożoną rzeczywistość. 0 ile żydowska teologia po Zagładzie za swój początek ma stanowcze odrzucenie retrybutywnej teodycei przymierza z jej pojęciami

\footnotetext{
${ }^{71}$ Siftej Szlomo..., s. 243.

${ }^{72}$ Literatura dotycząca teologii po Zagładzie jest zbyt bogata, by wskazać tu choćby wyłącznie najważniejsze pozycje źródłowe. Za dobre wprowadzenie do tematu może służyć książka Braitermana (God) After Auschwitz.
} 
grzechu i kary, o tyle Szlomo Zalman Unsdorfer oraz inni ultraortodoksyjni rabini, których wojenne zapiski przetrwały, stosowali to właśnie wytłumaczenie dla prześladowań i cierpienia ${ }^{73}$. W 1962 r. Richard Rubenstein obscenicznym nazwał pogląd, zgodnie z którym Zagłada była aktem boskiej woli i karą za grzechy $^{74}$. Jego odczucia były i pozostają dość powszechne. Opisywanie Zagłady w kategoriach boskiego planu i Hitlera jako „rózgi bożego gniewu” jest dla nas po prostu nie do przyjęcia.

Kazania Unsdorfera, w moim przekonaniu, sugerują, że nasza reakcja nie jest wcale tak oczywista, jak może nam się wydawać. Naturalnie można w tym miejscu zwrócić uwagę na dwie rzeczy. Pierwsza - można argumentować, że Unsdorfer sam zrezygnował ze stosowania schematu winy i kary w odniesieniu do prześladowań, których był świadkiem i ofiarą. Jest to niewątpliwie fakt. W jego kazaniach obecna jest zarówno teodycea w jej najbardziej klasycznym wydaniu, jak i antyteodycea milczenia i protestu. Natura tekstu nie pozwala nakreślić w myśleniu Unsdorfera jasno wytyczonej ewolucji, zmierzającej od tradycyjnej teodycei do jej zanegowania. Czego w tych kazaniach również nie ma, to choćby śladowe wątpienie $\mathrm{w}$ to, że opatrzność sprawuje kontrolę nad wydarzeniami. Wola Boga mogła stać się niezrozumiała, a nawet przerażająca, ale dla Unsdorfera pozostała wolą Boga. Myślenie paradygmatyczne umożliwiało mu wpisanie prześladowań w ciągłość żydowskiej historii, która w swojej istocie była z tego punktu widzenia opowieścią o nadzwyczajnym związku łączącym Boga z Izraelem, o związku, którego istnienie i trwałość nie podlegały najmniejszym wątpliwościom.

Drugie pytanie, które można w tym miejscu zadać, jest następujące: czy kazania Unsdorfera należy traktować jako reakcję na Zagładę? Jego wiedza na temat skali prześladowań była ograniczona. Z całą pewnością bardzo odmienna od tej, którą w latach powojennych miał Richard Rubenstein. W tym sensie można zatem powiedzieć, że Unsdorfer nie mógł zdawać sobie w pełni sprawy z teologicznych konsekwencji Zagłady, ponieważ o Zagładzie tej w istocie rzeczy nie wiedział. Myślę, że jest to trafne zastrzeżenie, choć problematyczne wydaje mi się to, iż zdaje się ono zakładać z góry, że judaizm, pewne jego formy czy aspekty, nie jest - na przykład dlatego że z jakichś powodów być nie może - odporny na wstrząsy historii. Z przeprowadzonych studiów nad interpretacjami Zagłady

${ }^{73}$ Mam tu na myśli szczególnie rabinów Szlomę Zalmana Ehrenreicha oraz Isakchara Tejchtala, o których piszę w History, Metahistory, and Evil. Esz Kodesz stanowi odmienny przypadek. Rabin Kalonimus Kalman Szapiro, przynajmniej wedle niektórych interpretacji, jednoznacznie i wcześnie (moim zdaniem już we wrześniu 1939 r.) odrzucił retrybutywną teodyceę, a w swoich ostatnich zapiskach dał wyraz radykalnemu zwątpieniu w istnienie samej relacji przymierza. Co do tego ostatniego nie ma zgody między intepretorami Esz Kodesz.

${ }^{74}$ Richard L. Rubenstein, After Auschwitz: Radical Theology and Contemporary Judaism, Indianapolis: Bobbs-Merrill, 1966, s. 52-53. 
w myśli ultraortodoksyjnej w latach powojennych ${ }^{75}$ wynika jednak przeciwna konstatacja, taka mianowicie, że Zagłada nie stanowiła dla tej formy żydowskiej myśli religijnej tak wielkiego wstrząsu, jak dla żydowskich teologów, takich jak Richard Rubenstein, Emil Fackenheim, Eliezer Berkovits czy Arthur Cohen, którzy odrzucili tradycyjne rozumienie Boga jako Pana Historii, a wraz z nim klasyczną teodyceę z powodów z Zagładą niezwiązanych ${ }^{76}$.

\section{BIBLIOGRAFIA}

Assmann Jan, Guilt and Remembrance: On the Theologization of History in the Ancient near East, „History and Memory” 1990, nr 1.

Berger Peter, The Sacred Canopy: Elements of a Sociological Theory of Religion, New York: Anchor Books, 1969.

Braiterman Zachary, (God) After Auschwitz: Tradition and Change in Post-Holocaust Jewish Thought, Princeton, NJ: Princeton University Press, 1998.

Bregman Marc, Past and Present in Rabbinic Literature, „Hebrew Annual Review” 1978, nr 2.

Caplan Kimmmy, The Holocaust in Contemporary Israeli Haredi Popular Religion, „Modern Judaism" 2002, t. 22, nr 2.

Cohen Gershon D., Esau as Symbol in Early Medieval Thought [w:] idem, Studies in the Variety of Rabbinic Cultures, Philadelphia: The Jewish Publication Society, 1991.

Cohen Shaye J.D., The Destruction: From Scripture to Midrash, „Prooftexts” 1982, t. 2, nr 1.

Cooper Alan, The Message of Lamentations, „Journal of the Ancient Near Eastern Society” 2001, t. 28, nr 1.

Dobbs-Allsopp Frederick William, Tragedy, Tradition and Theology in the Book of Lamentations, „Journal for the Study of the Old Testament” 1997, t. 22, nr 74.

Dobbs-Allsopp Frederick William, Weep, O Daughter of Zion: A Study of the City Lament Genre in the Hebrew Bible, Rome: Editrice Pontificio Instituto Biblico, 1993.

Ebenstein Ruth, Remembered Through Rejection: Yom Ha-Shoah in the Ashkenazi-Haredi Daily Press, „Journal of Israel Studies” 2003, t. 8, nr 3.

Fackenheim Emil L., God's Presence in History, New York: Harper and Row, 1970.

Fatran Gila, Haim maawak al hisardut: hanhagat Jehudej Slowakia ba-Szoa 1938-1944, Tel Awiw: Moreszet i Institute of Contemporary Jewry, 1992.

Fishbane Michael, Revelation and Tradition: Aspects of Inner-Biblical Exegesis, „Journal of Biblical Literature" 1980, t. 99, nr 3.

Freedman Harry, Jacob and Esau. Their Struggle in the Second Century, „Jewish Bible Quarterly" 1995, t. 23, nr 2.

\footnotetext{
${ }^{75} \mathrm{Na}$ ten temat zob.: Gershon Greenberg, Ultra-Orthodox Jewish Thought about the Holocaust since World War II, in The Impact of the Holocaust on Jewish Theology, red. Steven T. Katz; Dina Porat, New York: New York University Press, 2005; „Amalek's Accomplices” Blaming Zionism for the Holocaust: Anti-Zionist Ultra-Orthodoxy in Israel during the 1980s, "Journal of Contemporary History" 1992, t. 27, nr 4; Ruth Ebenstein, Remembered Through Rejection: Yom Ha-Shoah in the Ashkenazi-Haredi Daily Press, „Journal of Israel Studies” 2003, t. 8, nr 3; Kimmy Kaplan, The Holocaust in Contemporary Israeli Haredi Popular Religion, „Modern Judaism” 2002 , t. 22, nr 2 .

${ }^{76}$ Ten wątek rozwinęłam w eseju Richard Rubenstein and the Death of „Ghetto Judaism” („Shofar" 2015, t. 33, nr 3) oraz w History, Metahistory, and Evil.
} 
Greenberg Gershon, Shlomo Zalman Unsdorfer: With God Through the Holocaust, „Yad Vashem Studies" 2003, t. 31.

Greenberg Gershon, The Suffering of the Righteous According to Shlomo Zalman Unsdorfer of Bratislava, 1939-1944 [w:] Remembering for the Future: The Holocaust in an Age of Genocide, red. John Roth, New York: Palgrave, 2001.

Greenberg Gershon, Ultra-Orthodox Jewish Thought about the Holocaust since World War II [w:] The Impact of the Holocaust on Jewish Theology, red. Steven T. Katz, New York: New York University Press, 2005.

Gregerman Adam, Building on the Ruins of the Temple: Apologetics and Polemics in Early Christianity and Rabbinic Judaism, Tubingen: Mohr Siebeck, 2016.

Hacohen Malachi, Jacob and Esau: Jewish European History Between Nation and Empire: A Jewish European History, Nowy Jork: Cambridge University Press, 2019.

Hadas-Lebel Mireille, Jerusalem against Rome, Leuven: Peeters, 2005.

Heinemann Isaac, Darchej haaggada, Jerozolima: Magnes Press, 1970.

Heinemann Isaac, The Reasons for Commandments in Jewish Thought from the Bible to the Renaissance, Boston: Academic Studies Press, 2008.

Heinemann Joseph, The Nature of Aggadah [w:] Midrash as Literature, red. Geoffrey Hartman, Sanford Budick, New Haven: Yale University Press, 1986.

Kaminsky Joel S., Corporate Responsibility in the Hebrew Bible, Sheffield: Sheffield Academic Press, 1995.

Kaplan Kimmy, The Holocaust in Contemporary Israeli Haredi Popular Religion, „Modern Judaism" 2002, t. 22, nr 2.

Kraemer David, Responses to Suffering in Classical Rabbinical Literature, New York: Oxford University Press, 1995.

Krawcowicz Barbara, Paradigmatic Thinking and Holocaust Theology, „The Journal of Jewish Thought and Philosophy" 2014, t. 22, nr 2.

Krawcowicz Barbara, Richard Rubenstein and the Death of „Ghetto Judaism”, „Shofar" 2015, t. 33, nr 3.

Langer Gerhard, „Brother Esau?” Esau in Rabbinic Midrash [w:] Encounters of the Children of Abraham from Ancient to Modern Times, red. Antti Laato, Pekka Lindqvist, Leiden: Brill, 2010.

Larrimore Mark, The Book of "Job": A Biography, Princeton: Princeton University Press, 2013.

Linafelt Tod, Surviving Lamentations: Catastrophe, Lament, and Protest in the Afterlife of a Biblical Book, Chicago and London: Chicago University Press, 2000.

The Literature of Destruction. Jewish Responses to Catastrophe, red. David Roskies, Philadelphia: The Jewish Publication Society, 1988.

Midrash Rabbah: Lamentations, tłum. A. Cohen, London: Soncino Press, 1951.

Mintz Alan, Hurban: Responses to Catastrophe in Hebrew Literature, Syracuse: Syracuse University Press, 1996.

Neusner Jacob, The Idea of History in Rabbinic Judaism, Leiden: Brill, 2004.

Neusner Jacob, The Midrash Compilations of the Sixth and Seventh Centuries, t. 1: Lamentations Rabbah, Atlanta: Scholars Press, 1989.

Neusner Jacob, Paradigmatic versus Historical Thinking: The Case of Rabbinic Judaism, „History and Theory” 1997, t. 36, nr 3.

Noth Martin, Überlieferungsgeschichtliche Studien. Die sammelnden und bearbeitended Geschichtswerke im Alten Testament (1943), wyd. 3, Darmstadt: Wissenschaftliche Buchgesellschaft, 1967; angielskie tłumaczenie części pierwszej: The Deuteronomistic History, Sheffield: Sheffield Academic Press, 1981. 
Porat Dina, „Amalek's Accomplices” Blaming Zionism for the Holocaust: Anti-Zionist Ultra-Orthodoxy in Israel during the 1980s, „Journal of Contemporary History” 1992, t. $27, \mathrm{nr} 4$.

Provan Ian, Lamentations, New Century Bible Commentary, Grand Rapids: Eerdman's Press, 1991.

Rankema Johan, Theodicy in Lamentations? [w:] Theodicy in the Word of the Bible, red. Johannes Cornelis de Moor, Leiden: Brill, 2003.

Römer Thomas C., The So-Called Deuteronomistic History: A Sociological, Historical and Literary Introduction, London: T\&T Clark, 2005.

Rothkirchen Livia, The Destruction of Slovak Jewry (1942-1944): A Documentary History, Jerusalem: Yad Vashem, 1961.

Rubenstein Richard, After Auschwitz: Radical Theology and Contemporary Judaism, Indianapolis: Bobbs-Merrill, 1966.

Russell D.R., The Method and Message of Jewish Apocalypic, London: SCM Press Ltd, 1964.

Spurling Helen, The Biblical Symbol of Edom in Jewish Eschatological and Apocalyptic Imagery [w:] Sacred Texts. Explorations in Lexicography, red. Juan Pedro Montferrer-Sela, Angel Urban, Frankfurt am Main: Peter Lang, 2009.

Stern David, Imitatio Hominis: Anthropomorphism and the Characters of God in Rabbinic Literature, „Prooftexts” 1992, t. 12, nr 2.

Stern David, Parables in Midrash: Narrative and Exegesis in Rabbinic Literature, Cambridge, MA: Harvard University Press, 1991.

The Tragedy of the Jews of Slovakia: 1938-1945. Slovakia and the "Final Solution of the Jewish Question", red. Wacław Długoborski, Jarosław Mensfelt, Oświęcim: Auschwitz-Birkenau State Museum, Banska Bystica: Museum of the Slovak National Uprising, 2002.

Trakakis Nick N., Anti-Theodicy [w:] The Cambridge Companion to the Problem of Evil, red. Chad Meister, Paul J. Moser, New York: Cambridge University Press, 2017.

Unsdorfer Szlomo Zalman, Siftej Szlomo, Brooklyn, NY: Balszon Printing, 1972.

Westermann Claus, Lamentations: Issues and Interpretation, Minneapolis: Augsburg Fortress, 1994.

Wolfson Elliot R., Venturing Beyond. Law and Morality in Kabbalistic Mysticism, New York: Oxford University Press, 2006.

Yerushalmi Yosef Haiym, Zachor: żydowska historia i pamięć, tłum. Mirosław Wójcik, Warszawa: ŻIH, 2014. 